\section{Animal welfare and veal trade}

SIR - Your leading article on animal welfare (Nature 373, 175-176; 1995) uses an old dodge by questioning the logic of the objections to the cruel veal trade. You refer to existing measures under which the arm of the law can react to ill-treatment of animals as if their purpose were adequate and usually achieved, and anyway arguably better than in Europe. The issue is not all-or-nothing, but the aim is continual improvement and reform.

The imbalance in the market for calves of dairy herds is an unnatural consequence of the way the farming industry has evolved, and you underestimate the power of the economic forces that foster cruel practices. As you say, the welfare of domestic animals is crucial for the psychic welfare of those who have care of them; but it is also important for the psychic welfare of the society that sells them into custodial cruelty.

Your picture of a "stage-army" of animal rights protesters is an absurd gut reaction of ignorance to the genuine display of popular feeling taking place at the dockside. Unfortunately, British governments have too long a history of resisting reform and giving way reluctantly after public demonstrations, often provoked into violence by the governments' own failure to understand.

Although you admit that the boundary of the unacceptable "must change with time and vary from one culture to another", you fail to appreciate that the objection is to supporting an alien culture and that the resistance to change is supported by economic interests in Britain. Obstructing a vehicle actually engaged in furthering a cruel practice is very different from violence carried out by extremists who are actually taking the logic of their view to the extremes which you argue should be applied rigorously.

Methods of public demonstration are not all of a piece, nor are they bound together by your narrow-eyed logic.

\section{R.S.Scorer}

The Farm and Food Society,

4 Willifield Way,

London NW11 7XT, UK

\section{Core database}

SIR - The first single base-pair substitution in a human gene underlying a genetic disorder was reported in 1979: a nonsense mutation in residue Lys17 in the $\beta$-globin gene resulting in $\beta$-thalassaemia ${ }^{1}$. Since then, more than 3,300 different point mutations have been identified in approximately 400 human genes. For the past five years, we have maintained a database comprising virtually all published single base-pair substitutions causing genetic disease. This database has proved very useful in analysing the frequency and location of human gene mutations ${ }^{2}$, although the accelerating rate of data generation is making the task of updating it increasingly difficult.

It has become apparent to us that an increasing proportion (about 10 per cent) of reported mutations are redundant and yet are published without reference to the first report of that lesion. We believe that this highlights the inability of both authors and editors/referees fully to survey current data. In order to avoid double publication, we suggest the adoption of a system that allocates an accession number to each novel mutation before acceptance for publication. Such a system has proved very successful for new gene/DNA sequences submitted to Genbank or the European Laboratory for Molecular Biology. This system could also provide the basis for the future collation of human mutation data by electronic transfer of information. 'Electronic publication' would serve to reduce greatly the considerable burden on human molecular genetics journals in which a large proportion of articles currently published are mutation reports.

We are happy for our database to form the core of such an endeavour. However, as we are not logistically in a position to establish a generally accessible facility ourselves, we call upon the molecular genetics community for ideas and suggestions as to how to make this database a practical reality.

\section{Michael Krawczak}

Institut für Humangenetik,

Medizinische Hochschule,

30623 Hannover,

Germany

David N. Cooper

Charter Molecular Genetics Laboratory, Thrombosis Research Institute,

Manresa Road,

London SW3 6LR, UK

1. Chang, J. C. \& Kan, Y. W. Proc. natn. Acad. Sci. U.S.A. 76 2886 (1979)

2. Cooper, D. N. \& Krawczak, M. Human Gene Mutation (Oxford, BIOS Scientific Publishers. 1993)

\section{Nutritional science by committee?}

SIR - Lewis Wolpert (Nature 373, 279; 1995) wrongly attributes to me the view that "scientific fact is no longer the result of . . . decisive experiment, but of negotiations of committees. ..". He received this idea from a review by Sally M. Horrocks (Nature 372, 329; 1994) of my book Protein and Energy: a Study of Changing Ideas in Nutrition. This is not my view. But I did discuss the work of certain committees, which, rather than determining scientific facts, were asked to make recommendations in areas where the 'facts' were agreed to be incomplete.

One United Nations committee of scientists was charged in the 1950 s with recommending which malnutrition problems should receive priority attention. They emphasized the protein-energy malnutrition in toddlers throughout the developing countries. As the weaning diets of these children were much lower in protein content and also bulkier than those in wealthier countries, they went on to recommend development of new weaning foods in poorer countries; and economists, development experts and industrialists were enlisted to help with problems such as who would manufacture these foods; who would distribute them; would the mothers use them; would their introduction discourage local dairy production, and so on. Unlike Horrocks, I see no corruption of science or scientists, when they contribute their expertise in such joint endeavours.

Another type of committee whose work I discussed recommends safe dietary allowances for people in different age groups and conditions. Paediatricians and dietitians understand that these are only 'best recommendations', which will be reconsidered as more information accumulates, but they do save individuals from having to try to make their own literature surveys for each nutrient.

With regard to the protein needs of toddlers, there are many reports of how malnourished babies in hospital quickly recover on diets with different types and levels of protein; also how healthy babies develop well on different diets. The committee had to judge how much weight to give to atypical results, how to adjust for the use of protein of different quality, and then what 'margin of safety' to add on, to allow for individual variability, when making a general recommendation. Professor Nevin Scrimshaw, working in Guatemala, wrote that one such recommendation was not adequate for children with repeated bouts of diarrhoea, because it ignored their subsequent need for catchup growth. He added: "the democratic approach to truth is a contradiction in terms". I quoted his phrase but in this context - making recommendations rather than stating facts - I added "the committee system is not perfect, but as with democracy, we know nothing better".

Lastly, I agree with Wolpert that the striking advances in biology in this century (such as the discovery and synthesis of vitamins and endocrines) are not social constructs, but "stand on their ability to reflect nature".

\section{Kenneth J. Carpenter}

Department of Nutritional Sciences,

University of California,

Berkeley, California 94720, USA 